\title{
$\left[{ }^{11}\right.$ C $]$ DASB
}
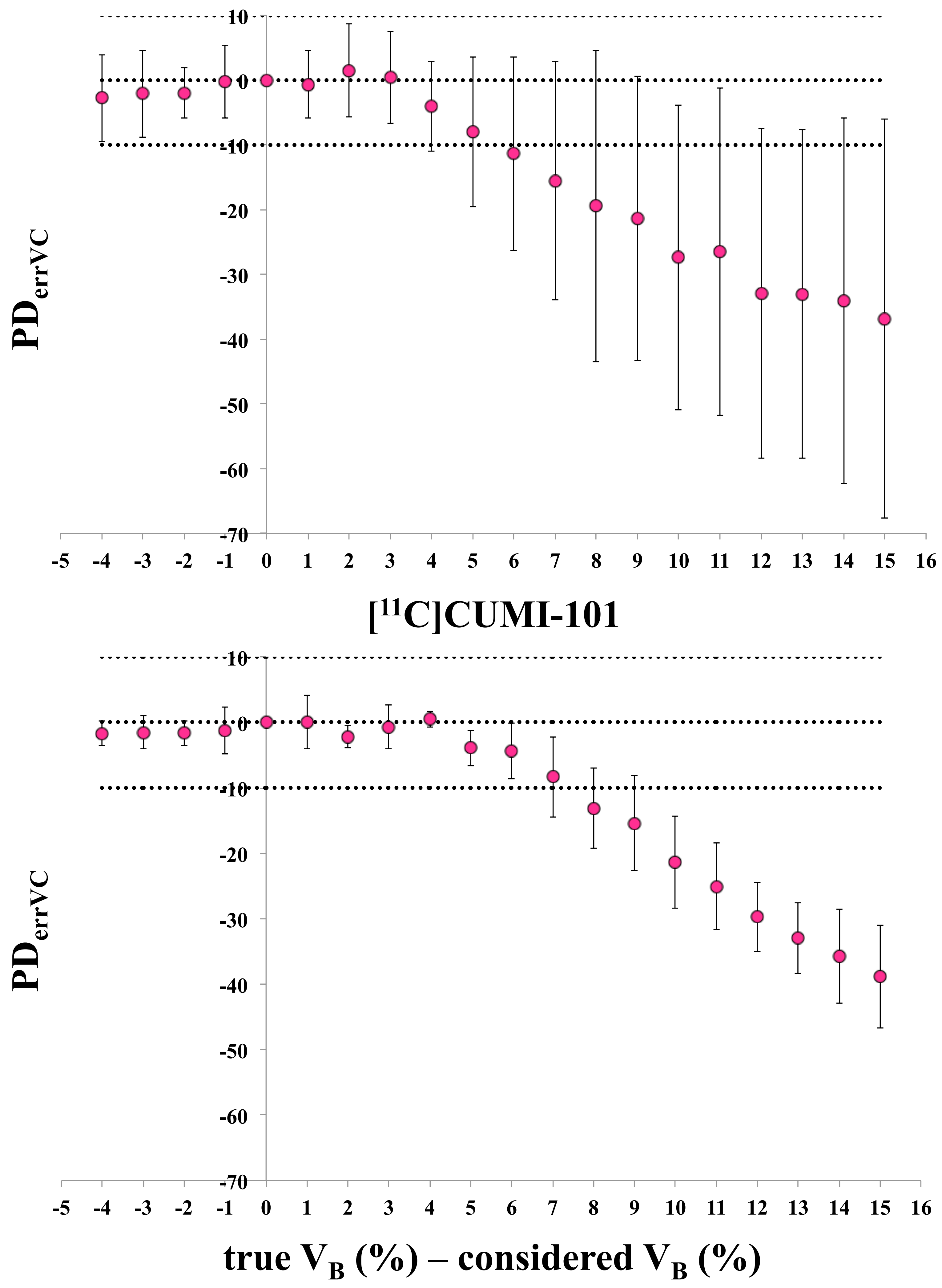